\title{
KONSEPSI AGAMA ISLAM DALAM AL-QURAN
}

\author{
Oleh : Ahmad Mujahid \\ ahmujahid69@gmail.com \\ UIN Alauddin Makassar DPK Unhas \\ Haeriyyah \\ haeriyyah@gmail.com \\ FIB UNHAS Makassar
}

\begin{abstract}
The problem with the diversity of Muslims is a religion without essence. Religion without substance. Having religion without practicing religious law. Having religion with the practice of sharia but minus the essence of being religious. This issue is discussed using the maudhuiy interpretation approach. Starting from the verses that use the term al-Islam, whether followed by the term al-dien or not, it is found that Islam refers to two meanings and or two conceptions, namely Islam as a religious institution and Islam as the essence of teachings. True Muslims are religious, not only limited to adhering to Islam as a religious institution but actually grounding Islam as teaching, namely actualizing Islamic teachings universally and holistically in life and life.

Keywords: The Essence of Religion; The Nature of Religion; al-Dīn; Essence of the Doctrine
\end{abstract}

\section{Abstrak}

Problematika keberagamaan umat Islam adalah beragama tanpa esensi. Beragama tanpa subtansi. Beragama tanpa pengamalan syariat agama. Beragama dengan pengamalan syariat namun minus hakekat beragama. Masalah ini dibahas dengan menggunakan pendekatan tafsir maudhuiy. Bertolak dari ayat-ayat yang menggunakan terma al-Islam baik diikuti oleh terma aldiin maupun tidak, ditemukan hasil bahwa Islam menunjuk dua makna dan atau dua konsepsi, yakni Islam sebagai institusi agama dan Islam sebagai esensi ajaran. Umat Islam sejati beragama, tidak hanya sebatas menganut Islam sebagai institusi agama, tetapi sejatinya membumikan Islam sebagai ajaran, yakni mengaktualisasikan ajaran Islam secara universal dan holistik dalam hidup dan kehidupan.

Kata Kunci: Esensi Beragama; Hakekat Beragama; al-Dīn; Esensi Ajaran 


\section{A. PENDAHULUAN}

Terma Islam, dapat terkait dengan nama institusi agama, yakni agama yang dibawa oleh Nabi Muhammad Saw. sebagai penutup para nabi Allah. Terma Islam juga dapat digunakan untuk menunjuk kepada esensi dan atau subtansi ajaran agama samawi, yakni agama yang diturunkan dari langit dan disampaikan oleh para nabi dan rasul yang diutus oleh Allah Swt. Kedua makna dari terma Islam tersebut merupakan satu kesatuan yang tidak terpisahkan, baik dalam penggunaan terma Islam tersebut diikuti oleh terma al-diin yang berarti agama, ataupun tidak diikuti oleh terma al-diin. Jadi dapat dipahami bahwa terma Islam meliputi nama agama dan sekaligus esensi ajaran agama itu sendiri. Oleh karena, dapat ditegaskan bahwa menganut agama dan atau beragama Islam, tidak cukup dengan hanya menganut institusi agamanya tanpa mengikut atau menghidupkan esensisubtansi dari ajaran agama Islam itu sendiri. Apabila pemahaman seperti dijadikan sebagai alat analisis-kritis dalam melihat cara keberagamaan umat Islam kekinian, maka pertanyaan yang menarik untuk dianalisis dan dikritisi adalah apakah umat Islam yang mengaku menganut Islam sebagai agama telah beragama secara esensial-subtansial? Dengan pertanyaan lain, apakah Islam baik dalam makna institusi agama maupun dalam makna esensi ajaran, telah nyata dan atau menjadi fenomena yang hidup dalam keberagamaan umat Islam? Ataukah kebanyakan (baca: untuk tidak mengatakan semua) umat Islam merasa cukup telah menganut agama Islam meskipun minus esensi-subtansi ajaran Islam itu sendiri?

Beberapa pertanyaan di atas, sangat relevan untuk dipertanyakan sekaligus untuk dijawab, apabila kita mencermati cara keberagamaan umat Islam di era kekinian, yakni tidak sedikit umat Islam yang telah mengaku menganut agama Islam, namun tidak mengetahui ajaran-ajaran Islam. Dengan perkataan lain, banyak di antara umat Islam yang buta esensi ajaran Islam itu sendiri. Lalu bagaimana umat Islam yang demikian, dapat menghidupkan dan atau membumikan esensi dari ajaran Islam dalam dirinya, pada keluarganya dan sosialmasyarakatnya. Selain itu, terdapat kelompok umat Islam yang mengilmui ajaran Islam, namun tidak memperaktekkan ajaran Islam sendiri. Kelompok ini pun, dapat dikategorikan sebagai kelompok umat Islam yang tidak sampai pada pembumian esensi ajaran Islam.

Ada lagi umat Islam yang mengamalkan dan memperaktekkan ajaran Islam, misalnya menegakkan shalat fardhu ditambah pelaksanaan shalat sunnah, berpuasa di bulan ramadhan dan bahkan rajin melaksanakan puasa sunnah, berzakat, berinfak, bersedekah dan bahkan telah menunaikan ibadah haji, namun pada kenyataannya kelompok umat Islam juga masih akrab dengan dosa, kemaksiatan, kejahatan, keburukan dan moralitas tercela (akhlak madzmumah). Dengan perkataan lain, kelompok umat Islam ini telah beragama secara lahir, namun minus esensi ajaran Islam. Pengamalan agama kelompok ini, tidak mampu dan atau disfungsi membentuk akhlak moralitas yang terpuji.

Salah satu karakter kelompok umat Islam adalah, mudah menyalahkan dan bahkan mengkafirkan umat Islam yang berbeda dengan pemahaman mereka. Karakter lainnya adalah kelompok umat Islam ini, cenderung mudah berselisih dengan umat Islam lainnya, bahkan sangat gampang mengdhalimi dan membunuh umat Islam lainnya yang telah dianggap kafir. Dalam sejarah Islam, kelompok ini dikenal dengan kelompok Khawarij. 
Dalam sejarah Islam, juga ditemukan contoh nyata, kejahatan yang dilakukan oleh umat Islam yang berpaham demikian, misalnya Ibnu Muljam. Dia adalah seorang penghafal alQuran, rajin baca al-Quran, rajin shalat, rajin puasa, bahkan tidak jarang meneteskan air mata ketika lagi menegakkan ibadah, namun Ibnu Muljam, dengan tanpa merasa bersalah sedikit pun telah mengayungkan pedangnya untuk membunuh Amirul Mukminin Ali, menantu Rasulullah Saw., orang yang digelari pintunya ilmu kenabiaan dan kerasulan. Ali adalah manusia yang digelari Karrama Allah wajhahu, yakni orang yang dimuliakan wajah dan rohnya oleh Allah. Fenomena cara keberagamaan seperti yang diperlihatkan oleh Ibnu Muljam, masih dapat dengan mudah ditemukan dan disaksikan dalam kehidupan umat Islam kekinian, khususnya umat Islam yang menganut Islam tekstual.

Peristiwa lain yang terjadi pada masa sahabat yang juga dapat menggambarkan keberislaman sebagian umat Islam yang hidup di masa tersebut terdistorsi esensi keberagamaannya adalah peristiwa pembunuhan khalifah Utsman bin Affan. Peristiwa ini, selanjutkan melahirkan peristiwa-peristiwa kelamnya lainnya dalam sejarah Islam, misalnya terjadinya perang saudara di antara para sahabat yakni Perang Shiffin dan Perang Jamal. Demikian pula peristiwa pembunuhan cucu kesayangan Rasulullah Saw, yakni Husain bin Ali as. di Karbala. Terlepas dari apa motif yang menjadi latar belakang dari berbagai peristiwa tersebut, namun yang pasti, berbagai peristiwa tersebut, tercatat sebagai peristiwa kelam dan gelap dalam sejarah Islam. Bukankah ini berarti menggambarkan tidak merealitasnya esensi ajaran Islam dalam berbagai peristiwa berdarah tersebut?

Berbagai peristiwa berdarah yang telah menggelapkan sejarah umat Islam, tampaknya juga dapat ditemukan pada era kekinian, misalnya perang yang terjadi di antara negara dan atau umat Islam di Timur Tengah. Bahkan tidak dapat dipungkiri, ada negara dan umat Islam yang bekerjasama dengan negara yang bukan Islam untuk memerangi negara umat Islam lainnya, misalnya saja perang yang pernah berlangsung tidak kurang dari 8-9 tahun antara dua negara Islam yakni Irak dengan Iran. Perang lainnya yang masih berlangsung hingga tulisan ini ditulis adalah perang yang berada dibawa kepemimpinan negara Saudi Arabiah melawan Suriah dan lain sebagainya. Juga keberadaan ISIS. Bukankah semua ini, juga menggambarkan bagaimana esensi ajaran Islam tidak merealitas dalam kehidupan umat Islam baik secara personal-individual, dalam kehidupan keluarga dan dalam kehidupan sosial-masyarakat bernegara.

Konteks keindonesiaan pun, berbagai peristiwa yang menggambarkan bahwa umat Islam jauh dari esensi ajaran Islam itu sendiri, mudah ditemukan, misalnya berbagai peristiwa yang menggambarkan intoleransi, radikalisme dan terorisme keberagamaan. Ketiga istilah ini memiliki relasi yang kuat, yakni intoleransi merupakan benih awal yang dapat menghadirkan radikalisme dan dari radikalisme kemudian mewujud dalam gerakan terorisme. Dan tak dapat dipungkiri bahwa intoleransi, radikalisme dan terorisme keberagamaan, dapat ditemukan di kalangan umat Islam, misalnya gerakan sweeping di tempat-tempat kemaksiatan. Terdapat dari kalangan umat Islam menganggap gerakan sweeping tersebut sebagai bentuk dari gerakan nahi mungkar. Oleh karena itu, bagi kelompok umat Islam yang berpaham demikian, menganggap gerakan sweeping tempat kemaksiatan merupakan perintah dari ajaran agama. 
Contoh lainnya adalah peristiwa teror pemboman dan atau bom bunuh diri. Tidak kurang dari 20 peristiwa pemboman telah terjadi atas nama agama di Indonesia. ${ }^{1}$ Gerakan pemboman yang paling terkenal adalah peristiwa bom Bali pada 2002. Pelaku gerakan ini, menyakini bahwa mati dan atau bunuh diri dalam peristiwa bom Bali merupakan bentuk dari mati syahid. Peristiwa lainnya yang juga menggambarkan intoleransi, radikalisme dan berpotensi menjadi terorisme adalah tindakan kekerasan terhadap kelompok Syiah di Sampang pada tahun 2012. Demikian beberapa peristiwa yang menggambarkan gerakan intolerasi, radikalisme dam terorisme. Ketiga gerakan ini sungguh sangat jauh dari esensi ajaran Islam, yakni sebagai rahmat bagi seluruh manusia dan alam semesta (rahmatan lil alamiin), sebagai agama perdamaian dan keselamatan.

Bertolak dari uraian di atas, pertanyaan yang dikaji lebih lanjut dalam tulisan ini adalah bagaimana beragama secara esensial-subtasial? Pembahasan masalah ini, didekati dengan pendekatan tafsir maudhuiy. Adapun tujuan dan manfaat yang hendak dicapai dari tulisan ini adalah dengan memahami esensial-subtansial keberagamaan dan mengamalkannya dalam kehidupan pribadi, keluarga dan sosial-masyarakat bernegara, diharapkan terciptannya kedamaian, ketentraman dan keselamatan dalam kehidupan pribadi, keluarga dan sosial-masyarakat-negara.

\section{B. TERMA $A D$-DIINDAN $A L$-ISLAMDALAM KEBAHASAAN}

Berdasarkan permasalahan yang hendak dijawab dalam tulisan ini, maka terma yang patut untuk dijelaskan dari sudut kebahasaan ada dua yaitu; pertama, terma al-diin dan kedua adalah al-Islam. Term al-diin adalah terma yang berakar pada huruf "dal, ya dan nun," yang menunjuk makna pokok ketundukan dan kerendahan. Maka terma al-diin menunjuk makna ketaatan. Jadi orang yang dinyatakan beragama apabila merasa memiliki agama, tunduk dan taat kepada agamanya. ${ }^{2}$ Al-Ashfahaniy mengatakan bahwa terma al-diin digunakan dalam makna ketaatan dan pahala serta digunakan dalam mengartikan sebuah syariat. Dalam makna ini, maka terma al-diin semakna dengan al-millah, yang berarti agama, namun penekanan pada terma al-diin digunakan untuk menggambarkan ketaatan dan ketundukan terhadap syariat. ${ }^{3}$ Dalam kitab Lisan al-Arab, kata al-diin menunjuk makna yang beraneka ragam, yakni;

1. Menguasai, menggagahi, menetapkan, memerintahkan, memaksa supaya taat, menggunakan wewenang terhadap bawahan dan menjadikannya sebagai seorang hamba yang patuh.

2. Mentaati, berkhidmat, melayani, mengabdikan diri kepada seseorang, mematuhi

\footnotetext{
${ }^{1}$ Terorisme di Indonesia.http://id.wikipedia.org/wiki/Terorisme di Indonesia.

${ }^{2}$ Abi Husain Ahmad Ibn Faris Ibn Zakariyah, Mu'jam Maqayis al-Lughat, Juz II (t.tp: Dar al-Fikr, t.th.), h. 319 .

3 Abi al-Qasim al-Husain Ibn Muhammad al-Ashfahaniy, al-Mufradat fi Gharib al-Quran (Mesir: Musthafa al-Bab al-Halabiy, t.th.), h. 765.
} 
perintahnya, tunduk di bawah pengaruh dan kekuasaannya.

3. Syara, agama, undang-undang, norma, aliran, sekte, adat istiadat atau tradisi.

4. Balasan, ganjaran, pengadilan dan perhitungan.

Makna kebahasaan dari terma al-diin, dapat dipahami bahwa esensi beragama adalah ikatan yang menuntut adanya kepatuhan, ketaatan, ketundukan seorang penganut agama terhadap syariat-syariat dan atau norma-norma agama yang dianutnya, dengan penuh kerendahan diri. Konsekwensi dari kepatuhan, ketaatan, ketundukan kepada syariat dan norma tersebut adalah adanya balasan, ganjaran di hari perhitungan.

Terma al-Islam, berakar pada huruf-huruf "sin, lam dan mim." Secara etimologis menunjuk makna pokok terbebas dari bahaya lahir maupun batin ${ }^{4}$ Dari akar kata ini dengan makna pokok terbentuklah beberapa derivasi yang menunjuk berbagai makna, namun semua maknanya dapat dikembalikan ke makna pokoknya, misalnya makna terbebas dari cacat, tunduk, patuh, memberikan, memeluk agama Islam, menyerahkan diri, berdamai, keselamatan, ketentraman dan lain-lain sebagainya ${ }^{5}$ Dari pengertian bahasa ini, dapat dipahami bahwa esensi makna dari terma Islam, adalah keselamatan, kedamaian, ketentraman, yang berasal dari ketundukan, ketaatan, dan penyerahan diri kepada Allah Swt dan atau dengan tunduk, patuh dan taat menegakkan ajaran Islam yang dianut.

Makna kedua terma yakni al-diin dan al-Islam yang membentuk frase "diin al-Islam," tergambar dengan jelas dan tegas bahwa esensi agama Islam adalah ketundukan, kepatuhan, ketaatan dan penyerahan diri kepada Allah yang menurunkan agama Islam, membuahkan keselamatan, kedamaian, ketentraman, baik secara lahir maupun secara batin. Dengan perkataan lain ketundukan, kepatuhan dan ketaatan dalam menegakkan ajaran agama membebaskan dari segala bentuk bahaya dan cacat baik secara lahir maupun secara batin. Makna dari esensi agama Islam akan semakin jelas diuraikan pada pembahasan beragama dalam perspektif al-Quran.

\section{ISLAM SEBAGAI AGAMA DAN SUBTANSI AJARAN}

Al-Quran menamai agama yang dibawa oleh Nabi Muhammad Saw. adalah dengan nama Islam. Terma Islam ditemukan penggunaannya dalam al-Quran sebanyak 8 kali. Dua ayat di antaranya tergolong dalam kelompok ayat makkiyah dan 6 ayat lainnya tergolong kelompok ayat madaniyah. ${ }^{6}$ Berikut uraian lebih lanjut ayat-ayat tentang Islam. QS. alAn'am/6: 125:

${ }^{4}$ Jamaluddin Muhammad Ibn Mukrim ibn Mansyur, Lisan al-Arab, Juz xvii (Bairut: Dar al-Ilmiyah, t.th.), h. 24-30

${ }^{5}$ Ibrahim Anis, Mu'jam al-Wasith, Juz I (Cet. VIII, T.tp: tp., t.th.), h. 446.

6 Muhammad Fuad Abd al-Baqi, Al-Mu'jam al-Mufakhras li Alfaz al-Quran al-Karim (Bandung: Diponegoro, t.th.), h. 453. 


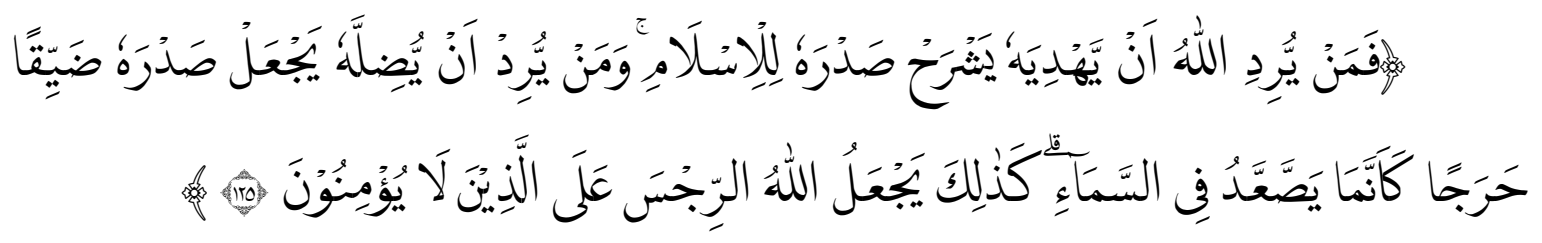

Terjemah:

"Barangsiapa yang Allah menghendaki memberikan kepadanya petunjuk, niscaya Dia melapangkan dadanya untuk (memeluk agama) Islam. dan Barangsiapa yang dikehendaki Allah kesesatannya, niscaya Allah menjadikan dadanya sesak lagi sempit, seolah-olah ia sedang mendaki langit. Begitulah Allah menimpakan siksa kepada orangorang yang tidak beriman.”

QS. al-Zumar/39: 22:

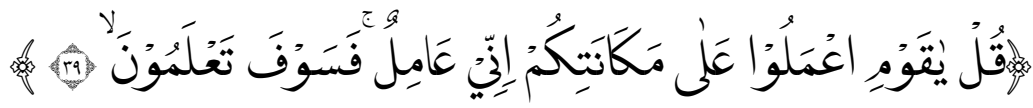

Terjemah

"Maka apakah orang-orang yang dibukakan Allah hatinya untuk (menerima) agama Islam lalu ia mendapat cahaya dari Tuhannya (sama dengan orang yang membatu hatinya)? Maka kecelakaan yang besarlah bagi mereka yang telah membatu hatinya untuk mengingat Allah. Mereka itu dalam kesesatan yang nyata."

Terma "Islam" pada kedua ayat makkiyah di atas tidak didahului dan atau diikuti oleh terma "ad-diin" yang berarti agama. Berbeda dengan penggunaan terma "Islam" pada kelompok ayat madaniyah, yakni ada yang didahului oleh dan atau dikaitkan dengan terma ad-diin, seperti dibahas kemudian. Ketiadaan term ad-diin mengikuti terma al-sslam, menurut penulis, pada kedua ayat di atas, dapat dipahami dalam 2 pemaknaan, yakni pertama adalah terma "al-Islam" bermakna subtansi ajaran Islam dan atau Islam sebagai ajaran. Kedua, terma al-Islam bermakna institusi keagamaan (agama) yang dibawa oleh Nabi Muhammad Saw. Kedua makna Islam tersebut satu kesatuan yang tak terpisahkan. Dengan perkataan lain, penggunaan terma Islam mencakup kedua makna tersebut secara bersamaan. Penggunaan term al-Islam tanpa diikuti oleh term al-diin, juga ditemukan dalam kelompok ayat-ayat madaniyah yakni pada 3 ayat, yakni QS. Shaf/61: 7; QS. al-Hujurat/49: 17 dan QS. al-Taubah/9: 74. Jadi penggunaan terma al-Islam dalam al-Quran lebih banyak tidak diikuti oleh terma al-diin. Menurut penulis, hal ini mengisyaratkan kuatnya makna yang telah dikemukakan di muka, yakni bahwa penggunaan terma al-Islam, selain menekankan Islam sebagai institusi keberagamaan yang dianggap benar di sisi Allah. Tidak ada institusi keberagamaan lainnya yang dianggap benar di sisi Allah pasca Muhamamd Saw. diutus oleh Allah sebagai Nabi dan Rasul Allah. Makna ini akan dibahas kemudian, namun isyarat makna yang tak kalah pentingnya untuk dikedepankan adalah bahwa dalam berislam tidak cukup dengan memasuki dan atau memeluk Islam sebagai institusi keberagamaan tanpa makna memiliki dan menghidupkan makna islam secara esensial-subtansial ajaran. Untuk lebih jelasnya berikut uraian lebih lanjut kedua ayat di atas.

Kandungan pokok ayat 125 surah ke 6 di atas mengemukakan bahwa kelompok 
sosial yang dianugerahi dan atau berada dalam petunjuk Allah adalah dada mereka lapang terhadap Islam baik sebagai subtansi ajaran maupun sebagai institusi keberagamaan. Sebaliknya kelompok sosial yang berada dalam kesesatan adalah dada mereka sesak dan sempit terhadap Islam baik sebagai subtansi ajaran maupun sebagai institusi agama. Kelompok sosial yang disebut terakhir ini, diumpamakan seperti orang yang sedang mendaki langit. Bukankah orang yang mendaki langit akan kesulitan dan mengalami sesak nafas karena kekurangan oksigen. Selanjutnya dalam klausa penutup ayat 125 ditegaskan bahwa sesungguhnya kesesatan dan kesempitan dada merupakan salah satu wujud siksaan Allah kepada kelompok sosial yang ingkar kepada Allah, yakni tidak beriman dan atau tidak menerima Islam sebagai ajaran dan atau sebagai institusi agama yang dibawa oleh Muhammad Saw.

Adapun kandungan ayat 22 surah ke 39, mempertanyakan kedudukan kedua kelompok sosial manusia tersebut, baik yang lapang dada atau yang sesak dan sempit dada terhadap Islam sebagai institusi keberagamaan dan atau sebagai subtansi ajaran, yakni apakah keduanya sama atau berbeda? Jawaban atas pertanyaan ini, dapat dipahami dari klausa lanjutan ayat 22 tersebut, yakni bahwa keduanya tidaklah sama. Kelompok sosial yang dada mereka lapang terhadap Islam berada pada cahaya Allah. Sementara kelompok sosial yang dada mereka sesak dan sempit terhadap Islam, hati mereka menjadi keras dan membatu. Kelompok sosial yang disebut terakhir ini, tidak pernah mampu berzikir mengingat Allah dan mereka berada dalam kelompok sosial yang tersesat dan mereka berada pada kecelakaan yang sangat besar.

Mencermati kandungan kedua ayat di atas, dipahami keduanya memiliki keterkaitan atau munasabah yang kuat, yakni keduanya saling menafsirkan dan atau menjelaskan. Pesan utama dari kedua ayat tersebut adalah bahwa Islam baik sebagai ajaran dan atau sebagai institusi agama, apabila diterima dengan lapang dada, maka itu petanda telah berada dalam petunjuk Allah dan dipenuhi cahaya ilahiah. Sebaliknya apabila Islam disikapi dengan dada yang sesak dan sempit, dengan perkataan lain ditolak, maka itu pentanda telah berada dalam kesesatan yang nyata, ketiadaan iman dan memperoleh siksaan.

Menurut penulis, rumusan sementara yang dapat dikemukakan secara tegas, jelas dan terbantahkan dari kedua ayat di atas terkait dengan Islam, baik sebagai subtansi ajaran maupun sebagai institusi keagamaan adalah bahwa dalam berislam dibutuhkan kelapangan dada sebagai lawan dari kesesakan dan atau kesempitan dada (shadrun). Dengan perkataan lain, berislam baik dalam makna institusi agama maupun sebagai subtansi ajaran terkait dengan kualitas hati, yakni baik kualitas yang dipenuhi cahaya dan atau lawannya kualitas hati yang keras (qalb qasiyah). Kualitas hati yang keras dalam berinteraksi dengan Islam merupakan petanda penolakan terhadap Islam. Karakteristiknya adalah tidak mampu berzikir mengingat Allah. Dalam pandangan al-Quran, hati yang buruk seperti ini merupakan salah bentuk "rijs", yakni kualitas hati yang sesak dan sempit bahkan mengeras dan membatu serta berada dalam kesesatan (dhalal) yang nyata. Berbeda dengan kualitas hati yang lapang dalam beriteraksi dengan Islam merupakan petanda penerimaan terhadap Islam. Karakteristiknya adalah hatinya bercahaya, berada dalam petunjuk (hudan). Dengan 
perkataan lain, dalam menerima Islam sebagai subtansi ajaran dan atau isntitusi agama yang dibawa oleh Nabi Muhammad Saw. tidak cukup dengan pengakuan lisan, tetapi memerlukan kelapanan dada dan atau hati. Jadi apabila seseorang mengaku berislam tetapi hatinya tidak lapang terhadap ajaran Islam maka sesungguhnya dapat dikatakan bahwa keislamannya belumlah mantap. Bahkan dapat dikatakan, belum beriman. Seperti ditegaskan dalam klausa penutup ayat 125 surah ke 6, yakni kelompok sosial yang dada dan atau hati mereka sesak dan atau sempit terhadap Islam, dinyatakan secara tegas sebagai kelompok sosial yang tidak beriman.

Keterangan lain yang juga patut ditegaskan adalah bahwa keberislaman dan keimanan adalah dua hal yang tidak terpisahkan satu sama lain. Keduanya berada dalam logika simultan. Informasi lain yang juga urgen untuk dikemukakan adalah bahwa keberislaman seseorang tidak dapat lepas dari Allah sebagai pemberi petunjuk. Dengan perkataan lain, keberislaman seseorang tidak dalam kemandiriannya tanpa Allah yang memberi petunjuk. Keterangan ini ditegaskan dalam ayat yang juga menggunakan terma alIslam yakni QS. al-Hujurat/49: 17.

Klausa yang menjadi fokus pembahasan dari kandungan kedua ayat di atas adalah klausa "yasrah shadrahu li al-Islam" dan atau "syaraha Allah shadrahu li al-Islam." Klausa pertama digunakan pada ayat 125 surah ke 6 dan klausa kedua ditemukan dalam ayat 22 surah ke 39. Ibnu Katsir mengemukakan beberapa riwayat tentang makna klausa "yasyrah shadruhu li al-Islam." Inti makna dari klausa tersebut adalah nur yang dimasukkan ke dalam dada orang yang bersangkutan. Dan di antara tandanya adalah selalu ingat hari kembali kepada Allah yakni hari kiamat. Senantiasa berusaha menjauhi perkara-perkara dunia yang menipu dan bersiap-siap untuk mati sebelum datangnya kematian. Keterangan lain yang dikemukakan oleh Ibnu Katsir sebelum dia mengemukakan beberapa riwayat yang dikemukakan di atas, Ibnu Katsir mengemukakan pandangan Ibnu Abbas yang menyatakan yang dimaksud dengan klausa inti di atas adalah Allah melapangkan dadanya kepada ajaran tauhid dan iman kepada Allah. ${ }^{7}$

Shihab dalam Tafsir al-Misbah menulis keterangan tentang makna klausa inti di atas, yakni klausa inti tersebut mengisyaratkan makna penerimaan ajaran Islam dan iman. Lebih lanjut Quraish menulis bahwa gabungan kata "yasyrah dengan shadra" menunjuk makna memperjelas dan menerangkan keterangan bahwa cahaya ditanamkan ke dalam hatinya. Dan dengan cahaya itu, ia menerima kebenaran dan mudah serta jelas jalan untuk meraihya. ${ }^{8}$ Keterangan yang tidak jauh berbeda dikemukakan oleh az-Zuhaili. Dia menulis bahwa yang dimaksud dengan klausa "yashrah shadruhu li al-slam" adalah Allah melapangkan dada seseorang untuk menerima keimanan dan kebaikan serta memasukkan cahaya ke dalam hatinya sehingga hatinya menjadi lapang dan menerima kebaikan. Al-Zuhaili menegaskan bahwa makna yang dikemukakannya disebutkan dalam riwayat-riwayat yang

${ }^{7}$ Imanuddin Abi al-Fida' Ismail Ibnu Katsir al-Qusyairi al-Dimasqiy, Tafsir al-Quran al-Adhim, Juz I (Cet. I, Bairut: Dar al-Fikr, 1990), h.195-196.

${ }^{8}$ M. Quraish Shihab, Tafsir al-Misbah: Pesan, Kesan dan Keserasian Al-Quran, Juz 4 (Jakarta: Lentera Hati, 2002), h. 284. 
disandarkan kepada Rasulullah Saw dan Ia juga mengemukakan keterangan yang dikemukakan oleh Ibnu Abbas, seperti yang dikemukakan oleh Ibnu Katsir. ${ }^{9}$

Sementara Thabaththaba'iy dalam Tafsir al-Mizan mengemukakan makna klausa "yashrah shadrahu li al-Islam" dengan makna seseorang berserah diri kepada Allah, yakni sungguh dadanya luas dan lapang dalam berserah diri kepada Allah dan atau dalam memeluk agama Islam. Orang tersebut menerima keyakinan yang benar yakni ajaran tauhid dan menegakkan amalan diniyah yang saleh. Lebih lanjut Thabaththabai menulis bahwa kelapangan dada ini karena bashirahnya dipenuhi cahaya. Berbeda dengan orang yang bashirahnya buta maka ia tidak mampu membedakan kebenaran dan kebatilan, tidak mampu membedakan kejujuran dengan kebohongan. ${ }^{10}$

Berangkat dari uraian di atas, penulis ingin tegaskan bahwa dalam menganut Islam dan atau dalam berislam diperlukan keseriusan, dan bukan sekedar pengakuan lisan tanpa pembenaran dan atau penerimaan hati selapang-lapangnya. Syarat utama dan pertama dari kebenaran keberislaman umat Islam adalah ketika hatinya telah lapang dalam menerima Islam baik sebagai ajaran dan atau sebagai institusi agama yang dibawa oleh Nabi Muhammad Saw. Dengan perkataan lain, keberislaman tanpa kelapangan hati, tidak atau belumlah sempurna, meskipun ia telah diakui bahwa ia telah masuk dalam area Islam atau telah memeluk Islam. Oleh karena itu, dalam berislam diperlukan gerakan penyempurnaan keberislaman, sampai seorang yang mengaku Islam menjadi muslim. Seorang yang beragama Islam tidak boleh tidak dia mesti menjadi muslim. Sebelum ia menjadi muslim maka keislamannya belumlah sempurna dan hanya berada pada wilayah lahir Islam semata minus makna batin atau hakiki Islam. Tegasnya keberislamannya tidak sampai pada puncak keislaman. Dalam konteks makna ini, maka Allah memerintahkan agar Islam dimasuki atau dianut secara menyeluruh, universal dan holistik. Islam yang seperti ini, dalam alQuran disebut Islam kaffah. Seperti ditegaskan dalam QS. al-Baqarah/2: 208:

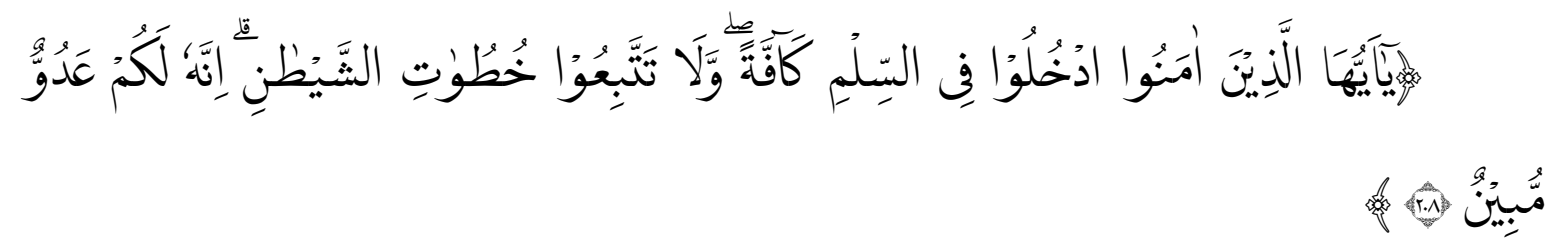

Terjemah:

Hai orang-orang yang beriman, masuklah kamu ke dalam Islam keseluruhan, dan janganlah kamu turut langkah-langkah syaitan. Sesungguhnya syaitan itu musuh yang nyata bagimu.

Kandungan ayat ini menegaskan perintah Allah agar menganut Islam secara holistik, universal, menyeluruh atau berislam kaffah. Perintah berislam secara kaffah diikuti

\footnotetext{
${ }^{9}$ Wahbah Zuhaili, Tafsir al-Munir Aqidah, Syariah Manhaj. Terj. oleh Abdul Hayyi al-Kattani dkk dari judul aslinya: "Tafsir al-Munir fi al-Aqidah wa al-Syariat wa al-Manhaj," Juz 4 (Jakarta: Gema Insani, 2015), h. 323.

${ }^{10}$ Muhammad Husain al-Thabaththaba'iy, al-Mizan fi Tafsir al-Quran, Juz 7 (Bairut: Muassasah alIlmiah, 1997), h. 353-354).
} 
dengan larangan mengikuti langkah-langkah setan. Ini mengisyaratkan makna bahwa setan dengan berbagai langkah-langkahnya adalah musuh yang paling nyata bagi orang yang berislam secara kaffah. Dengan perkataan lain, mengikuti langkah-langkah setan kontraproduktif dengan keberislaman secara kaffah. Mengikuti langkah-langkah setan dapat merusak keberislaman yang kaffah.

Keterangan lain yang patut dicermati dari kandungan ayat 208 di atas, adalah bahwa perintah memasuki dan atau menganut Islam secara kaffah di satu sisi dan larangan mengikuti langkah-langkah setan di sisi lain, diserukan kepada kelompok sosial yang telah beriman. Menurut penulis, ini mengisyaratkan makna bahwa keberislaman secara kaffah, hanya dapat diwujudkan ketika iman telah ada dan telah merasuk ke dalam hati. Tanpa iman dalam hati maka keberislaman dengan benar atau kaffah sulit terwujud, sebaliknya mudah terjebak dan terjatuh dalam langkah-langkah setan. Jadi keberislaman yang benar, hakiki dan kaffah adalah ketika hati telah lapang dengan ajaran agama Islam dan itu telah menjadi petanda bahwa keimanan pun telah merasuk ke dalam hati. Pemahaman yang demikian ini, sesungguhnya telah diisyaratkan dalam ayat 125 surah ke 6. Di mana dalam klausa penutup ayat 125 tersebut ditegaskan bahwa siksa atau rijs ditimpakan kepada kelompok sosial yang tidak beriman. Pertanyaannya adalah siapa kelompok sosial yang tidak beriman? Jawabanya adalah mereka yang hatinya tidak lapang terhadap ajaran agama Islam, yakni hatinya sesak dan sempit terhadap Islam, mereka menolak Islam.

Orang atau kelompok sosial yang hatinya sesak terhadap Islam, baik sebagai ajaran atau sebagai agama adalah orang atau kelompok sosial yang tidak beriman. Sebaliknya orang yang hatinya lapang terhadap Islam baik sebagai ajaran maupun sebagai institusi agama, maka itu pertanda di hatinya ada iman. Keterangan dan pemahaman yang demikian ini, semakin jelas dan tegas apabila ditautkan dengan kandungan ayat 22 surah ke 39. Di mana dalam ayat yang disebut terakhir ini, dikemukakan bahwa orang yang lapang dadanya dengan Islam, maka hatinya dipenuhi cahaya Allah. Sebaliknya orang yang sesak atau sempit hatinya terhadap Islam, yakni hatinya membatu dan tidak mampu berzikir kepada Allah dalam arti yang seluas-luasnya dan mereka berada dalam kesesatan yang nyata, artinya orang yang hatinya tanpa Islam dan Iman adalah kelompok sosial yang sesat secara pasti, nyata dan jelas. Tegasnya Islam dan Iman mesti merasuk ke dalam hati, bukan sekedar pengakuan lisan. Di sisi inilah tampak dengan jelas keislaman dan keimanan adalah dua ajaran al-Quran yang tidak terpisahkan. Keduanya bagaikan dua sisi mata uang yang menyatu. Dengan perkataan lain, Islam sejatinya menjadi muslim dan iman sejatinya menjadi mukmin. Muslim dan mukmin adalah satu kesatuan yang tak terpisahkan. Oleh karena itu, sekali lagi penulis tegaskan, orang yang mengaku berislam atau beriman sejatinya menegakkan gerakan penyempurnaan keislaman dan keimanannya sampai menjadi muslim dan mukmin.

Setelah menganalisis uraian paragraf akhir ini, sangat mungkin lahir pertanyaan. Bagaimana dengan kandungan ayat 14 surah al-Hujurat. Kandungan ayat mengemukakan, pengakuan kelompok sosial Arab Badui bahwa mereka telah beriman. Lalu Allah menolak pengakuan keimanan mereka, karena keimanan mereka belum merasuk ke dalam hati, namun Allah perintahkan kepada mereka agar berkata bahwa diri mereka telah menganut 
Islam. Bukankah dari kandungan ayat 14 surah ke 49 ini, dapat dipahami bahwa kelompok sosial Arab Badui itu telah diakui keislamannya oleh Allah meskipun tanpa iman di hati? Bukankah ini mengisyaratkan bahwa Islam dan iman itu berbeda? Bukankah juga menggambarkan bahwa Islam duluan baru Iman sebagai suatu hirarki?

Kandungan ayat 14 surah ke 49 tersebut tidak bertentangan dengan kandungan ayat 125 surah ke 6 dan atau surah ke 39 ayat 22, demikian pula ayat 208 dalam surah ke 2 yang telah diuraikan di atas. Berikut QS. al-Hujurat/49: 14:

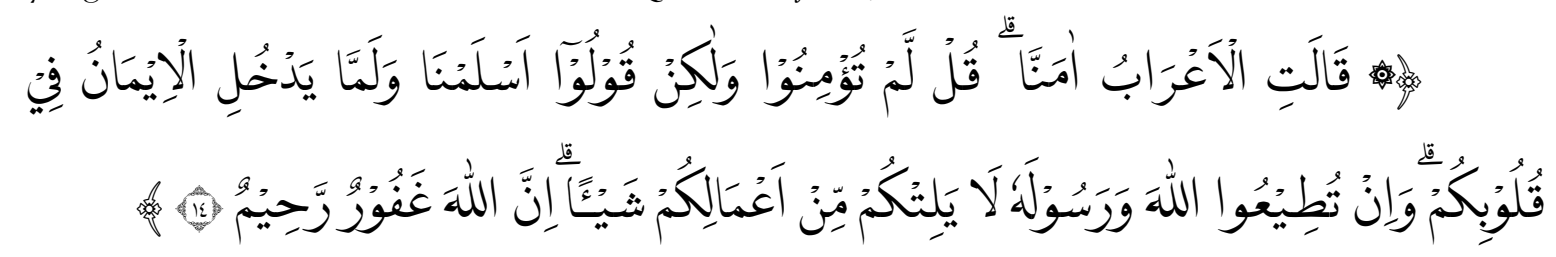

Terjemah:

Orang-orang Arab Badui itu berkata: "Kami telah beriman". Katakanlah: "Kamu belum beriman, tapi Katakanlah 'kami telah tunduk', karena iman itu belum masuk ke dalam hatimu; dan jika kamu taat kepada Allah dan Rasul-Nya, Dia tidak akan mengurangi sedikitpun pahala amalanmu; Sesungguhnya Allah Maha Pengampun lagi Maha Penyayang."

Menurut penulis, kandungan ayat 14 surah ke 49 tersebut menggambarkan bahwa keberislaman kaum Arab Badui, baru tahap elementary. keIslaman yang belum diikuti dengan kelapangan dada, yakni keislaman tanpa iman. Model, tahapan dan kualitas keberislaman tanpa iman sangat mungkin terjatuh dalam kemunafikan dan sangat mudah mengikuti langkah-langkah setan, seperti digambarkan dalam QS. Taubah/9: 74. Sebagai perbandingan al-Quran kemudian mengemukakan keberislaman dan keimanan kelompok sosial Arab Badui yang benar, yakni keberislaman dengan iman yang telah merasuk ke dalam dada dan diterima dengan lapang dada, seperti disebutkan dalam ayat 99 surah atTaubah, yakni:

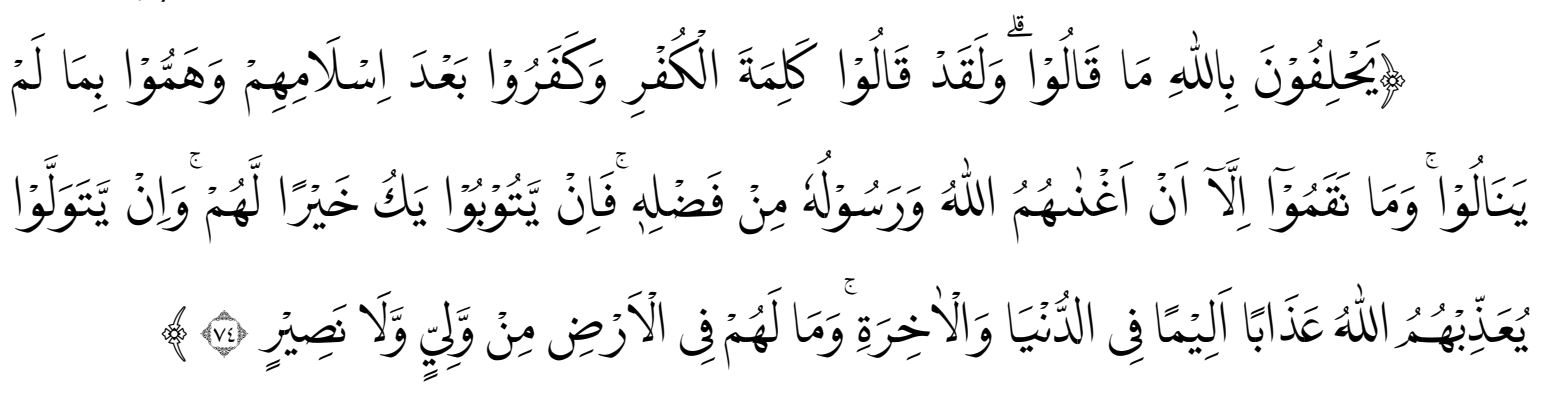

Terjemahnya :

Mereka (orang munafik) bersumpah dengan (nama) Allah, bahwa mereka tidak mengatakan (sesuatu yang menyakiti Muhammad). Sungguh, mereka telah mengucapkan perkataan kekafiran, dan telah menjadi kafir setelah Islam, dan menginginkan apa yang mereka tidak dapat mencapainya; dan mereka tidak mencela (Allah dan Rasul-Nya), sekiranya Allah dan Rasul-Nya telah melimpahkan karunia-Nya kepada mereka. Maka jika mereka bertobat, itu adalah lebih baik bagi mereka, dan jika mereka berpaling, niscaya Allah akan mengazab mereka dengan azab yang pedih di dunia dan akhirat; dan mereka tidak mempunyai pelindung dan tidak (pula) penolong di bumi. 
Kandungan ayat 99 surah ke 9 ini mengemukakan tentang keimanan kelompok sosial Arab Badwi yang berbeda dengan keimanan kelompok sosial Arab Badui yang dikemukakan dalam ayat 14 surah ke 49 di atas. Kelompok sosial Arab Badui yang dikemukakan dalam ayat 99 ini adalah mereka yang keimanannya kepada Allah dan hari Kemudian telah dibenarkan karena telah merasuk ke dalam hati mereka. Buktinya mereka memandang dan menjadikan apa yang dinafkahkan di jalan Allah, sebagai jalan untuk mendekatkan diri mereka kepada Allah dan sebagai jalan untuk memperoleh doa rasul. Mereka adalah kelompok sosial Arab Badui yang memiliki iman yang benar. Mereka dekat dengan Allah dan mencintai Rasulullah Saw. Mereka adalah kelompok sosial yang dimasukkan ke dalam rahmat Allah yakni surga. Keimanan yang demikian inilah yang merupakan keimanan yang sesungguhnya. Kelompok sosial Arab yang disebutkan dalam ayat 14 surah 49 sejatinya melakukan gerakan dari Islam menjadi muslim, dengan demikian mereka telah mukmin, yakni iman telah merasuk ke dalam hati. Dengan begitu mereka dapat dimasukkan dalam kelompok sosial Arab Badui yang disebutkan dalam ayat 99 surah ke 9.

Rumusan lain yang patut dikemukakan dari kandungan klausa "yashrah shadrahu li al-Islam" adalah bahwa yang dimaksud terma al-Islam dalam klausa tersebut adalah Islam sebagai ajaran dan Islam sebagai institusi agama. Keterangan ini telah diulang-diulang sebelumnya, namun menurut penulis butuh penegasan konsepsi dengan mengemukakan dalil dan alasan penguat, supaya semakin jelas dan tegas. Adapun yang penulis maksud dengan dalil atau alasan penguat atas konsepsi tersebut adalah dalil munasabah antara kandungan klausa "yashrah shadrahu li al-slam" sebagai klausa sentral di atas dengan kandungan ayat sebelum dan sesudahnya dalam surahnya masing-masing, yakni klausa sentral yang terdapat pada ayat 125 surah ke 6 diperpautkan dengan ayat-ayat sebelumnya. Kandungan ayat-ayat sebelumnya yakni ayat 122-124 surah al-An'am, mengemukakan tentang kelompok sosial kafir dan kelompok sosial pendosa. Kedua kelompok sosial yang disebut terakhir ini, tidak beriman kepada ayat-ayat Allah yang berisi ajaran-ajaran Islam. Mereka melakukan gerakan perdurhakaan terhadap ajaran-ajaran Islam. Oleh karena itu kedua kelompok sosial yang ingkar kepada ajaran-ajaran Islam ditimpakan kehinaan di sisi Allah dan siksa yang pedih di akhirat.

Adapun perpautan ayat 125 dengan kandungan ayat sesudahnya yakni ayat 126 dalam surah ke 6, penulis pahami bahwa yang dimaksud makna Islam adalah Islam sebagai ajaran atau Islam sebagai institusi agama. Dipahami demikian, karena pada ayat 126-127 ditegaskan bahwa Islam merupakan jalan Allah yang lurus. Dan kelompok sosial yang menerima Islam baik sebagai ajaran dan sebagai institusi agama, bagi mereka diperuntukkan surga sebagai tempat kedamaian di sisi Allah. Dari dalil munasabah ini, dapat ditegaskan bahwa yang dimaksud dengan kelompok sosial kafir dan kelompok sosial pendurhaka adalah bukan saja menolak Islam sebagai institusi keberagamaan tetapi juga menolak dan mengingkari Islam sebagai subtansi ajaran. Sebaliknya yang dimaksud dengan muslim sejati adalah menerima Islam dengan kelapangan dada baik sebagai institusi keberagamaan, terlebih lagi Islam sebagai subtansi ajaran. Dengan perkataan yang tegas, bahwa seorang yang mengaku menganut agama Islam sejatinya menjadi seorang muslim 
atau seorang mukmin.

Konsepsi beragama seperti diuraikan berdasarkan kedua ayat makkiyah di atas merupakan cara keberagamaan yang diterima dan dibenarkan di sisi Allah, yakni keberagamaan yang subtansial-esensial. Model keberagamaan yang berbeda dengan konsepsi keberagamaan subtansial-esensial tersebut tertolak di sisi Allah, seperti dapat dipahami dari QS. Ali Imran/3: 19 dan 85:

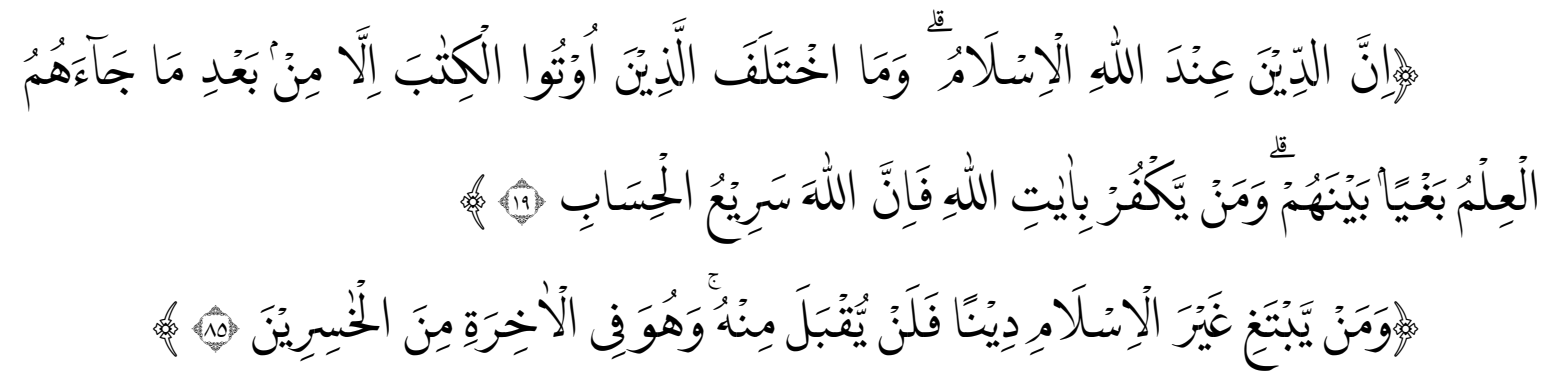

Terjemahnya :

19. Sesungguhnya agama di sisi Allah ialah Islam. Tidaklah berselisih orang-orang yang telah diberi Kitab kecuali setelah mereka memperoleh ilmu, karena kedengkian di antara mereka. Barangsiapa ingkar terhadap ayat-ayat Allah, maka sungguh, Allah sangat cepat perhitungan-Nya.

85. Dan barangsiapa mencari agama selain Islam, dia tidak akan diterima, dan di akhirat dia termasuk orang yang rugi.

Kandungan ayat 19 surah ke 3 di atas menginformasikan bahwa agama yang benar di sisi Allah adalah Islam. Sedangkan kandungan ayat 85 menginformasikan bahwa agama selain Islam tertolak di sisi Allah. Kandungan kedua ayat yang terdapat dalam surah Ali Imran di atas, saling menguatkan satu sama lain. Menurut Ibnu Katsir ayat 19 menginformasikan bahwa tidak ada agama yang diterima di sisi Allah dari seseorang selain Islam, yakni mengikuti rasul-rasul Allah yang diutusNya setiap saat hingga berakhir pada Rasulullah Saw, yakni Muhammad Saw sebagai penutup para Nabi dan rasul Allah (khatamun nabiyiin). Risalah Muhammad Saw merupakan penutup semua jalan menuju Allah. Tidak ada lagi jalan menuju Allah selain jalan yang diajarkan Rasulullah Saw. Siapa yang mencari jalan untuk bertemu dengan Allah selain syariat yang disampaikan oleh Rasulullah Saw, maka tidak ada pengabulan di sisi Allah. Selanjutnya Ibnu Katsir menguatkan pandangannya dengan mengutip ayat 85 surah Ali Imran. ${ }^{11}$ Keterangan yang senada oleh Ibnu Katsir dikemukakan oleh az-Zuhaili yang mengatakan bahwa agama itu diturunkan dengan dua tujuan yaitu: pertama, meluruskan dan membenarkan akidah yakni mentauhidkan Allah dan kedua adalah mendidik dan memelihara jiwa agar memiliki niat yang ikhlas karena Allah. ${ }^{12}$

Sementara Thabaththabaiy mengatakan bahwa ayat 19 surah ke 3 ini mengemukakan bahwa agama di sisi Allah hanya satu, tidak ada perbedaan di dalamnya. Allah tidak memerintahkan hamba-hambaNya kecuali beragama dengan agama yang satu ini. Dan semua kitab dan ayat-ayat yang diturunkan kepada para nabi dan rasul Allah

\footnotetext{
${ }^{11}$ Ibnu Katsir, Tafsir al-Quran al-Adhim, juz I, h. 380.

${ }^{12}$ Wahbah Zuhaili, Tafsir al-Muniir, 2, h. 214.
} 
adalah menjelaskan tentang agama yang satu ini. Agama yang dimaksud adalah agama Islam, yakni agama yang mengajarkan ketundukan kepada kebenaran dengan keimanan dan perbuatan yang benar dan ikhlas. Islam adalah menerima dengan lapang dada seluruh pengetahuan dan perintah Allah. Allah mengharapkan kepada hamba-hambaNya agar mengikuti agama ini. ${ }^{13}$

Dari keterangan yang disampaikan oleh beberapa pakar tafsir di atas dapat dipahami bahwa dari sudut subtansial-esensial ajaran, Islam adalah ajaran seluruh Nabi dan Rasul Allah yang diutus pada setiap saat. Di mana seluruh Nabi dan Rasul Allah tersebut mengajarkan tauhid. Pemahaman ini diisyaratkan dari perpautan ayat 19 surah Ali Imran dengan ayat sebelumnya yakni ayat 18, di mana pada ayat 18 tersebut Allah mempersaksikan diri-Nya bahwa tidak ada ilah selain Dia. Persaksian ini diikuti oleh para malaikat dan para pemilik ilmu, namun demikian, menarik untuk dikemukakan bahwa ajaran tauhid sebagai subtansi ajaran Islam yang dibawa oleh para nabi Rasul Allah yang telah diutus sebelum Nabi Muhammad Saw. tidak disebut sebagai agama Islam, hanya disifati dengan sifat Islam. Berbeda dengan Islam yang dibawa oleh Muhammad Saw, yakni dinamai secara khusus sebagai institusi agama dan sekaligus dengan makna subtansi ajaran Islam. Dengan demikian, dapat ditegaskan bahwa Islam yang dibawa oleh Nabi Muhammad Saw, adalah Islam yang mencakup makna institusi agama dan makna subtansi atau esensi ajaran, seperti telah banyak dijelaskan sebelumnya.

\section{KESIMPULAN}

Penggunaan terma al-Islam dalam al-Quran menunjuk kepada dua makna pokok yaitu pertama Islam sebagai ajaran subtansial-esensial ilahiah. Ajaran Islam ini disampaikan oleh seluruh nabi dan rasul Allah yang telah diutus pada setiap zaman dan berakhir pada kerasulan Muhammad Saw. Makna kedua adalah Islam sebagai institusi keberagamaan. Makna kedua ini dikhususkan kepada Islam yang dibawa oleh Muhammad Saw. sebagai nabi dan rasul penutup. Kedua makna pokok tersebut menggambarkan bahwa berislam secara benar adalah tidak cukup dengan mengaku memeluk Islam tanpa penegakan subtansi-esensial ajaran Islam itu sendiri. Dengan perkataan lain, keberislaman yang dibenarkan di sisi Allah adalah memeluk Islam secara nyata dan mengamalkan ajaran Islam secara faktual dalam segala dimensi kehidupan. Dan tidak ada jalan yang dapat menyampaikan seorang manusia kepada Allah selain jalan Islam yang dibawa oleh Muhammad Saw, baik dilihat dari sudut institusi keberagamaan maupun dari sudut subtansi ajaran.

\footnotetext{
${ }^{13}$ Muhammad Husain Thabaththaba'iy, al-Mizan fi Tafsir al-Quran, III, h. 139.
} 


\section{DAFTAR PUSTAKA}

Al-Quran al-Karim.

Abd al-Baqi. Muhammad Fuad. Al-Mu'jam al-Mufakhras li Alfaz al-Quran al-Karim. Bandung: Diponegoro, t.th.

Al-Ashfahani. Abi al-Qasim al-Husaini Ibn Muhammad. Al-Mufradat fi Gharib al-Quran. Mesir: Mushtafa al-Bab al-Hakabiy, t. th.

Anis, Ibrahim. Mu'jam al-Wasith. Bairut: Dar al-Fikr, t.th.

Ibnu Faris al-Zakariah, Abi Hasan Ahmad. Mu'jam Maqayis al-Lughat. Bairut: Dar al-Fikr, t.th.

Ibnu Mansyur, Abi al-Fadhil Jamal al-diin Ibn Mukram. Lisan al-Arab. Bairut: Dar al-Kitab alIlmiy, t.th.

Ibnu Katsir, 'Imanuddin Abi al-Fida' Ismail. Tafsir al-Quran al-Adhim. Bairut: Dar al-Fikr, 1990.

Shihab. Quraish. Tafsir al-Misbah, Pesan. Kesan dan Keserasian Al-Quran. Jakarta: Lentera Hati. 2002.

Thabaththabaiy. Al-Allamah al-Sayyid Muhammad Husain. Al-Mizan fi Tafsir al-Quran. Bairut: Muassasah al-A'lamiy li al-Mathbuat. 1997.

Az-Zuhaili, Wahbah. Tafsir al-Munir, Aqidah, Syariah dan Manhaj. Terj. Oleh Abdul Hayyie alKattani dari judul aslinya " al-Tafsir al-Munir fi Aqidah, wa asy-Syariah wa alManhaj.” Jakarta: Gema Insani, 2013. 